\title{
EVALUATING THE IMPACT OF COVID- 19 ON WOMEN IN MOROCCO AND TUNISIA
}

\author{
SIPOS XÉNIA ZSUZSANNA
}

PHD CANDIDATE AT THE DOCTORAL SCHOOL OF INTERNATIONAL RELATIONS AND

POLITICAL SCIENCE (INTERNATIONAL RELATIONS AND SECURITY STUDIES SUBPROGRAM),

CORVINUS UNIVERSITY OF BUDAPEST

XENI-KHALI2008@LIVE.FR

The COVID-19 pandemic has globally amplified and brought to the surface the difficulties of vulnerable groups, including women engaged in rural activities. Even before the outbreak of the pandemic, the Middle East and North Africa (MENA) region was strongly affected by a significantly high unemployment rate (42.8\%) among young people aged 15 to 24 . The fact that $61.8 \%$ of the female labour force in Morocco and $70 \%$ of it in Tunisia are involved in the agricultural sector serves as an additional obstacle to realizing gender equality. Besides the application of statistical indicators, the article also works with qualitative data collected from interviews that were conducted with four representatives or members of local Tunisian NGOs and four activists of Moroccan women's rights organizations. On one hand, it cannot be denied that international relations themselves are strongly strongly dominated by men. On the other hand, taking into consideration the complex interdependence of the international political order and its effects on decision-makers and sub-state actors alike, the analysis states that despite the political, historical, economic, and cultural characteristics of Morocco and Tunisia, the pandemic can serve as a catalyst for women's rights organizations to act for the improvement of women's conditions.

Keywords gender inequality, Maghreb, complex interdependence, sub-state actors, COVID-19 


\section{Introduction}

Despite the significant efforts of governments to ensure all the necessary measures and protection against the discrimination of women following the Arab Spring protests that swept over the region of the Middle East and North Africa (MENA) starting from December 2010 the remnants of traditional norms in patriarchal society are still seen as a major obstacle to achieving gender equality. A recent study conducted by the OECD, the Centre of Arab Women for Training and Research (CAWTAR), and the International Labour Organization (ILO) focusing on women's empowerment in Morocco, Tunisia, Egypt, and Jordan revealed that the GDP of the MENA region could be increased by $47 \%$ or more if there was equal participation in the labour force between men and women (OECD-ILO-CAWTAR, 2020: 17).

The reason for highlighting Morocco and Tunisia from the other MENA countries is to compare the outstanding indicators and measures taken by these countries to ameliorate the position of women in the political and economic field. Tunisia has emerged in the region as a pioneer of women's rights. Following the country's independence in 1956, the Tunisian political arena was centralized by the first president of the country, Habib Bourguiba, who started a westernized modernization process in politics and economics (Sadiqi, 2008: 449). As a result of the adoption of the Personal Status Code (PSC) $)^{1}$, in 1956 the modernization process also had a significant impact on women's rights (abolition of polygamy, protection of the rights of women to divorce, child custody reforms, and establishing a minimum age for marriage). Moreover, in 1958 the Tunisian president introduced compulsory education for young women and people living in rural areas (Chabchoub, 2014: 128). Contrary to Tunisia, in Morocco the dominance of traditional norms derived from a patriarchal society and the consolidation of these norms in the family code (Mudawwana) adopted in 1957 determined the inferior position of women since the beginning of the country's independence in 1956. Resulting from the absence of a controlled, top-down approach linked to the historical and social characteristics of Morocco, the amelioration of women's rights in the country required a more significant presence and measures from non-governmental organizations, which found themselves in a quite favourable environment following the accession of King Mohamed VI to the throne in 1999 (Ennaji, 2021: 165-166).

By applying the feminist approach of international relations (IR), the article builds primarily on Ann Tickner's gendered perceptions in IR and states that the question of women's rights requires a complex analysis in which all circumstances and key players - including decision-makers as well as sub-state actors of the political arena - are taken into consideration. Regarding the emergence of sub-state actors from the end of the 1970s, the study links Joseph Nye and Robert Keohane's complex interdependence theory to the topic of the presence of gender inequalities. It is important to emphasize that the analysis of the gendered states' behaviours in the international political arena and the multilateral framework of the question of women's rights would exceed the length of the current study. Therefore, the article focuses on bottom-up and top-down relations and their role in shaping the political,

\section{Hungarian Journal of African Studies (Afrika Tanulmányok)}


economic, social and cultural position of women in Morocco and Tunisia during the COVID-19 pandemic. By evoking some basic social indicators, the article demonstrates the biggest socioeconomic challenges women faced even before the outbreak of the pandemic. Interviews with four representatives or members of Moroccan and Tunisian NGOs and locals contribute to reinforcing the main argument that is despite the negative impacts of COVID-19, the pandemic can urge local NGOs to cooperate for the benefits of women in the region.

\section{A postmodern feminist approach to the question of gender inequalities in IR: gendered international relations in the world of complex interdependence}

When approaching the question of women's participation in political and economic fields and analysing the causes of existing inequalities between men and women in general, regardless of the current pandemic situation, the study deals with the postmodern approach of feminism in international relations. In this regard, Ann Tickner must be mentioned. Based on the marginalization of women in policy-making and the presence of different stereotypes, Tickner described international relations as male-dominated and deeply "gendered". According to Tickner, the elimination of gender hierarchies requires a more equal (c.a. 50\%) participation of women in all levels of decision-making, including foreign and military policies (Tickner, 1992: $8-9,96)$. As women's role in society is shaped by various social and cultural norms that often serve as constraints limiting gender equality, these inequalities penetrate the internal political arena where measures of decision-makers are taken accordingly. Moreover, these socially created patterns also have a significant impact on the behaviour of states transnationally (Keohane, 1998: 193-194).

R.W. Connell's concept of hegemonic masculinity is indispensable to better understand the origins of the unequal relationship between men and women. In his work Gender and Power, Connell stated that the dominance of men over women is a culturally idealized form created by the society that helps to maintain patriarchal social order (Jewkes et al., 2015: 113). Similarly to Connell, Joan Scott also shed light on the fact that gender relations are in fact power relations that derive from the traditional division of roles between the sexes (private versus public sphere), which further reinforce women's inferior status in the political arena (Scott, 1986: 1069). Radical feminist Cynthia Enloe elaborated a different approach when examining the existing inequalities between men and women, and instead of analysing the causes of the weak participation of women in key decision-making processes, she tried to find answers to the absence of women in the fields of politics and security (Ruiz, 2005: 5). Thus, contrary to the previous findings, Enloe stated that in fact women are present in the political and military arena, but institutional processes have always reinforced the dominance of men over women.

As mentioned in the introduction, the transnational framework - i.e. multilateral and regional efforts and cooperation, including previous women conferences such as the Beijing Conference on Women in 1995 and previous conventions and protocols - will not be part of the current analysis because of the study's limited scope. 
Therefore, the study focuses on the origins of gender inequalities from the bottom-up perspective and the relationship of sub-state actors with decision-makers. Moreover, it also touches upon the question of to what extent sub-state actors can collaborate to ameliorate the situation of women in Morocco and Tunisia in light of the global pandemic. Following a brief review on the feminist IR approach, the study also starts off by discussing the inferior position of women that is the outcome of a male-dominated society. Regarding the level of sub-state actors, the previous findings would mean that the position of women is shaped by the particular cultural and social circumstances in Tunisia and Morocco. Similar to interstate relations, anarchy predominates on the level of sub-state actors, but certain conditions can drive representatives of NGOs to collaborate for the benefits of Moroccan and Tunisian women. As a result, the bottom-up patterns penetrate the level of the states, having a significant impact on decision-makers who face pressure to consider the particular features of society with their policy towards the question of gender equality. In this regard, a reverse process takes place and sub-state actors also shape the behaviours of states.

Regarding non-state actors, it is indispensable to underline that the 1970s and 1980s brought about a new hierarchical order. The emergence of global problems and their solutions required an approach that was totally different from the previous management of these challenges. This is how the phenomenon of complex interdependence emerged as a result of the appearance of new political actors - i.e. sub-state actors with a significant impact on decision-makers. While on the one hand nobody can deny that the traditional political order remains state-centric, on the order hand we cannot contest the fact that through mobilizing and monitoring activists, domestic and regional organizations also exert a significant influence not only on public opinion, but on government policies. According to Joseph Nye and Robert O. Keohane, in certain cases non-governmental actors have a greater impact on international processes than states themselves. Contrary to interstate activities, the main characteristics of transnational interactions is that they involve sub-state actors as well. Nye and Keohane stated that transnationalism has five effects on state behaviour: changes in attitude; the emergence of international pluralism; limitations on states to maneuver as a result of the alteration of the traditional state-centric order; an increased ability to influence other governments; and a more significant role of sub-state actors that sometimes overwrites the priorities of governments (Nye-Keohane, 1971: 331-332, 336-337). Sub-state actors constitute the focus of the article and the transnational framework will not be part of the current study. Therefore, the limited space for states to maneuver and the increased role of sub-state entities require further analysis in addition to the aforementioned changes. In the following section, the article aims to demonstrate the main socioeconomic challenges that the women of Morocco and Tunisia faced before the outbreak of the COVID-19 pandemic. Moreover, it will also provide a brief overview on the different policies of the two countries and the role of women's rights NGOs to cope with these problems. 


\section{The evolution of women's rights in Morocco and Tunisia: major challenges and their solutions}

When dealing with the question of women's rights in the Maghreb it is indispensable to mention that the evolution of women's rights cannot be separated from the economic, social, cultural, political and historical characteristics of Morocco and Tunisia. The modernity derived from the heritage of the French colonial past was built on a conservative, patriarchal society, which resulted in the co-existence of two competing paradigms. The existence of a more liberal way of thinking is well demonstrated in the will of carrying out necessary reforms that focused on the modification of the fundamental set of laws that regulate the status of women in everyday life (i.e. the family code). The aforementioned efforts resulted in the extension of women's rights and the assurance of greater access to education and political representation. However, on the other hand the presence of some traditional social practices, particularly in Morocco, is seen as a serious barrier to achieving gender equality (Kimani, 2008: Africa Renewal).

According to Moghadam (2014), the institutional legacy of the past, the role of women's rights organizations before and after the political transitionbeginning in December, 2010, all had a serious impact on the question of gender equality. The 1960s saw a general improvement in the health and economic conditions of women in the Maghreb. Moreover, the number of women enrolled in education and involved in decision-making also increased (Sadiqi, 2008: 451). While nobody can contest the growing influence of women's rights organizations from the 1960s and 1970s, it is certain that transnational activities and the fear of the emergence of political Islam from the 1980s also exercised pressure on decision-makers in the Maghreb region to act on behalf of women's empowerment. Education and women's economic and political participation also influenced the twelve objectives of the Beijing Platform for Action, adopted in 1995 during the Beijing Conference on Women's Rights (UN Women, 2015: 5). Moreover, these indicators are also crucial from the point of the Gender Inequality Index (GII) ${ }^{2}$, a human development index developed by the United Nations Development Programme (UNDP).

Concerning women's access to schooling, it must be mentioned that contrary to Tunisia, in Morocco education only became compulsory in 1963, five years later than in Tunisia. Between 1990 and 1991 school attendance showed significant differences between boys and girls ( $88 \%$ vs. $48 \%$ for 7 and 12 year-olds and $69 \%$ vs. $4.5 \%$ for 13 and 15 year-olds in favour of boys) (Sadiqi, 2008: 462-463). Although women's access to education improved in the 1990s and early 2000s, inequalities are still present. According to the official statistical data of $\mathrm{UNESCO}^{3}$, between 2012 and 2019 the presence of boys was $4 \%$ higher in primary education. This tendency also continued in secondary education between 2011-2012 and 2017-2019 with males outnumbering females by $5.87 \%$. However, when it comes to academic enrolment, women outnumbered men by $1 \%$ according to the latest data available from 2019 . Unfortunately, indicators of illiteracy are far from promising as Morocco has the highest illiteracy rate in the Maghreb (Sadiqi, 2008: 462) that impacts women living 
in rural areas the most (60\%). According to the latest UNESCO data from 2018, the illiteracy rate reached $35.4 \%$ for women and $16.7 \%$ for men who were 15 years old or more.

As explained in the theoretical framework for the article, the study addresses gender inequalities and applies the Gender Inequality Index (GII) developed by the UNDP. When analysing inequalities between Moroccan men and women in the field of reproductive health, empowerment, and the labour market, between 1995 and 2019 significant measures were taken by the government to reduce inequalities (the GII) from 0.722 to 0.454 (United Nations Development Programme, HDR) ${ }^{2}$. A gradual improvement also took place following the Arab Spring. However, despite the aforementioned developments, in 2019 Morocco occupied the $111^{\text {th }}$ place worldwide among the ranking of countries on the Gender Inequality Index. This ranking means that Morocco did even worse than Libya ( $56^{\text {th }}$ place) and Algeria $\left(103^{\text {rd }}\right.$ place $)$ in terms of unequal opportunities for women compared to men. The dimensions of the GII clearly demonstrated that in Morocco women's participation in the labour force and decision-making are key areas where improvements were urgently needed even before the outbreak of the COVID-19 pandemic. Concerning the women's share of the labour force, official statistical data from the High Commission of Planning (Haut Commisariat au Plan) is only available from 1999, showing a significant rise in the female unemployment rate from $8.8 \%$ in 2017 to $14.7 \%$ in $2020^{4}$. According to the GII, in 2019 female participation in the labour force was $21.5 \%$ compared to $70.1 \%$ for men $^{2}$. In connection with scholars of feminist IR theory who study the absence of women in decision-making, the percentage of women in the national parliament of Morocco only reached $18.4 \%$ in 2019 (20.5\% in the upper chamber and $11.7 \%$ in the lower house) according to the Inter-parliamentary Union (IPU) ranking. When compared with Tunisia or Algeria, Morocco remains the country with the weakest participation of women in the national parliament, despite the required $30 \%$ of representation stipulated in the Convention on the Elimination of all Forms of Discrimination Against Women (CEDAW) (Inter-parliamentary Union, 2003: 14). To achieve this objective the government will have to take additional steps.

As mentioned in the introduction, the evolution of women's rights in Tunisia followed a different path since its independence in 1956. The marginalisation of the tribal system and the relatively small size of the population of the country made the top-down approach led by a strong president (Habib Bourguiba) possible. Thus, state feminism enabled significant reforms to be carried out (Sadiqi, 2008: 449-450). However, on the other hand, these reforms were the outcome of a clearly defined westernized modernisation process that required a more educated and skilled labour force. In this regard, compulsory education was provided to girls in 1958, and Tunisian women were given the right to vote in 1959. As a result of the extended rights in the field of education, indicators demonstrated a significant improvement for women, which meant that the average years spent in school rose from 4.9 to 15.1 years between 1971 and 2010 (Mail, 2019: 2-4). Family planning in the 1960s and the legalisation of abortion in 1973 (Jomier, 2011: 6) also conformed to Bourguiba's 
modernisation process. While the aforementioned Personal Status Code (PSC) ensured formal equality (abolition of polygamy, women's consent to divorce, etc.), it did not eradicate inequalities between men and women. State feminism proved to be a political tool of the government to get rid of Islamists by practicing control over the religious sphere, as well as to conform to the international objectives of the women's rights framework. On one hand, the ratification of the international bill of women's rights, the CEDAW in 1985, and the increase of the quota in electoral positions to $20 \%$ by President Zin el-Abidine Ben Ali in 2004 were all clear indicators of the real intentions of the government concerning the question of women's rights. On the other hand, Tunisia's reservations (CEDAW, 1979: 67-68) made to the CEDAW, including inequality between men and women with respect to their children, inequality in marriage and its dissolution, guardianship, demonstrated the dichotomy of the government's approach to gender inequality (Inter-parliamentary Union, 2003: 95, 98). In this sense, the outbreak of the Arab Spring revolution in December 2010 brought about a new chapter for previously repressed women's rights organizations in which a more open debate on the role of women (e.g., drafting of the new constitution in 2014, law on equal heritage) became possible (Mail, 2019: 2-9, $11,13,17-18)$.

Regarding equal access to the field of education, the net enrolment rate in primary education was equal between the sexes until 2018 when the presence of boys was $1 \%$ higher than girls. According to the official statistical data of UNESCO, ${ }^{3}$ in secondary education the attendance of girls between 2011 and 2016 surpassed that of the boys and nearly doubled between this period (While in 2011 girls' school attendance rate surpassed that of boys by $6.6 \%$ this advantage increased to $12.4 \%$ in 2016). Concerning women's academic enrolment, it is important to underline that between the period of 2011 and 2019 an absolute dominance of women is seen in higher education. While in 2011 an advantage of $22.6 \%$ was demonstrated in favour of women, this ratio increased to $41.7 \%$ in 2019. In connection with the level of education, it is important to mention that contrary to Morocco, the illiteracy rate was only significant for the age group of 65 years and above where an $81 \%$ illiteracy rate is present versus $48.6 \%$ for men according to the latest UNESCO statistical data from 2014.

Taking the Gender Inequality Index (GII) as a reference, with its 0.296 GII in 2019 , Tunisia occupied the $65^{\text {th }}$ place worldwide in the ranking of countries by the $\mathrm{UNDP}^{2}$ regarding countries with the lowest gender inequality. This ranking also means that five MENA countries (Bahrein, Kuwait, Qatar, Saudi Arabia and the UAE) did better than Tunisia in terms of ensuring equal opportunities for both sexes in the field of reproductive health, empowerment, and the labour market. The biggest gap was identified in the field of participation in the labour market where women aged 15 years and older made up only $23.8 \%$ of the labour market contrary to $69.4 \%$ for men. According to the Tunisian Bureau of Statistics, in 2014 only $20 \%$ of women living in rural areas possessed of a decent job and in some regions the unemployment rate surpassed $40 \%$. In the most marginalized regions, $61 \%$ of women worked in 
the most vulnerable agricultural sector and only $12 \%$ had access to medical and social services (Ministère de la Femme, de la Fertilité et de l'Enfance, 2017: 2). This percentage clearly shows that the low participation of women in the labour market and the conditions of rural women were worrisome even before the outbreak of the pandemic, aggravated by the growing political and social tensions from 2019. Regarding the dimension of empowerment of the GII, it must be mentioned that following the events of 2011 when the participation of women in the parliament only reached $26.27 \%$, in 2014 Tunisia surpassed the 30\% requirement set by the CEDAW. Moreover, in 2019 women occupied 78 out of the 217 seats, which meant a $35.9 \%$ representation ( $31^{\text {st }}$ place worldwide and first place among Arab countries). However, following the presidential elections of October 2019, a regression took place and according to the latest data of the IPU ${ }^{5}$, in 2020 only 54 seats were occupied by women out of the 217 , meaning a $24.9 \%$ representation in decision-making. Though a strategic decision, the nomination of Najla Bouden on 30 September, 2021 as the first female Prime Minister in Tunisia and the Arab world is seen as a unique and promising step for women's empowerment (Mazoue, 2021).

\begin{tabular}{|c|c|c|c|c|}
\hline \multirow{2}{*}{ Indicators } & \multicolumn{2}{|c|}{ Tunisia } & \multicolumn{2}{|c|}{ Morocco } \\
\hline & women & men & women & men \\
\hline $\begin{array}{l}\text { Net school enrolment } \\
\text { rate-primary education }\end{array}$ & $\begin{array}{c}114.93 \%(2018) \\
* \text { statistical } \\
\text { data from } 2019\end{array}$ & $\begin{array}{c}115.93 \%(2018) \\
* \text { statistical } \\
\text { data from } 2019\end{array}$ & $\begin{array}{l}112.73 \%(2019) \\
111.51 \%(2018)\end{array}$ & $\begin{array}{l}116.69 \%(2019) \\
116.11 \%(2018)\end{array}$ \\
\hline $\begin{array}{l}\text { Net school enrolment } \\
\text { rate - secondary educa- } \\
\text { tion }\end{array}$ & $\begin{array}{l}99.32 \%(2016) \\
\text { vs. } 95.28 \% \\
(2011)\end{array}$ & $\begin{array}{l}86.9 \%(2016) \\
\text { vs. } 88.63 \% \\
(2011)\end{array}$ & $\begin{array}{c}78.18 \%(2019) \\
\text { vs. } 61.52 \% \\
(2011) \\
\text { *statistical } \\
\text { data from 2016 }\end{array}$ & $\begin{array}{c}84.05 \%(2019) \\
\text { vs. } 71.31 \% \\
(2011) \\
\text { *statistical } \\
\text { data from } 2016\end{array}$ \\
\hline $\begin{array}{l}\text { Net school enrolment } \\
\text { rate-higher education }\end{array}$ & $41.7 \%$ (2019) & $22.6 \%(2019)$ & $38.1 \%(2019)$ & $39.1 \%$ (2019) \\
\hline $\begin{array}{l}\text { Literacy rate }-15 \text { years } \\
\text { and above }\end{array}$ & $72.2 \%$ & $86.1 \%$ & $64.6 \%$ & $83.3 \%$ \\
\hline $\begin{array}{l}\text { Literacy rate }-65 \text { years } \\
\text { and above }\end{array}$ & $24.4 \%$ & $55.8 \%$ & $19 \%$ & $51.4 \%$ \\
\hline $\begin{array}{l}\text { Participation in the } \\
\text { labour force }\end{array}$ & $23.8 \%(2019)$ & $69.4 \%$ (2019) & $20.5 \%(2019)$ & $70.1 \%(2019)$ \\
\hline $\begin{array}{l}\text { Share of seats in the } \\
\text { parliament }\end{array}$ & $\begin{array}{c}35.9 \%(2019) \\
(24.9 \% \text { in } \\
2020)\end{array}$ & $77.4 \%$ (2019) & $18.4 \%(2019)$ & $81.6 \%$ (2019) \\
\hline Gender Inequality Index & \multicolumn{2}{|c|}{$0.296(2019)$} & \multicolumn{2}{|c|}{$0.454(2019)$} \\
\hline
\end{tabular}

^ Table 1. Summary chart of Tunisia and Morocco based on the main indicators of gender inequalities Source: based on the statistical data from the official site of the Organisation des Nations Unies pour l'Éducation, la Science et la Culture. Institut de Statistique de l'UNESCO

Tunisia: http://uis.unesco.org/fr/country/tn;

Morocco: http://uis.unesco.org/fr/country/ma? theme=education-and-literacy

UNDP Human Development Reports: http://hdr.undp.org/en/home

IPU: https://data.ipu.org/women-ranking?month $=1$ \&year $=2021$ 
The brief outlook on the evolution of women's rights in Morocco and Tunisia proved that different social, political, historical, and cultural processes contributed to the construction and reconstruction of women's rights in both countries. However, the Arab Spring clearly demonstrated that democracy can only be realized $f$ it takes into consideration the social and economic needs of the most vulnerable groups (Moghadam, 2014: 141). Therefore, the evolution of women's rights is a bidirectional process: women's rights activist can push states towards the acceptance of certain reforms in favour of women, especially in socially or economically fragile periods such as the Arab Spring or the COVID-19 pandemic. This happened in Morocco with the reform of the family law in 2004 (Moghadam, 2014: 140) or in lifting some of its reservations to the CEDAW in 2011 (Dahlerup-Darhour, 2020: 15). Following this overview, the next chapter will identify the main consequences of the pandemic on women's rights.

\section{The social, economic, and political impact of the COVID-19 pandemic on wom- en's rights in Morocco and Tunisia}

The outbreak of the COVID-19 pandemic brought about new political and economic challenges that all governments had to face. This new situation required decisionmakers to adapt to new strategies and reconsider the question of gender equality. The new challenges emerging from the pandemic include growing inequalities in education and the labour market, namely the overrepresentation of women in agricultural and domestic work. Moreover, women also tend to suffer from the psychological effects of the pandemic as they are more liable to domestic violence resulting from the accumulated social and economic frustration.

According to the OECD report in 2020 that analyses the effects of the COVID-19 on gender inequalities in the MENA, women's school enrolment constituted one of the main challenges even before the pandemic, but the crisis brought about a higher

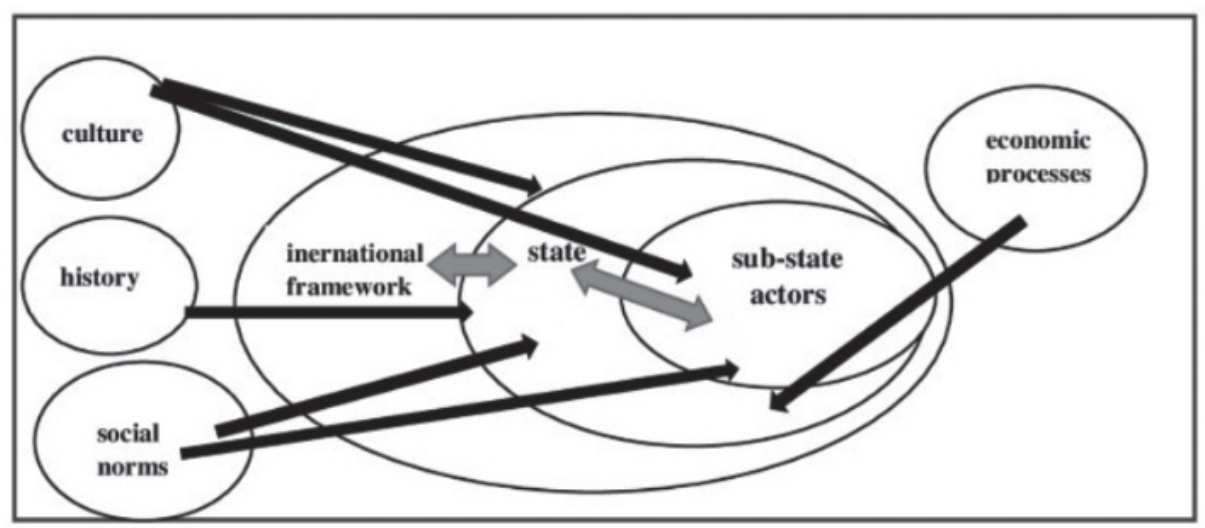

$\bigwedge$ Figure 1. The evolution of women's rights in the framework of international relations and sub-state actors.

Sipos Xénia Zsuzsanna: Evaluating the impact of COVID-19... 
number of women dropping out of the educational system. School dropout was much higher in remote rural areas with limited access to internet and other necessary materials for distance teaching (OCDE, 2020: 4-5). The second most serious effect of the pandemic includes issues related to the labour market and concerns about women involved in agricultural activities, exacerbating the inequalities women experienced before COVID-19. In Morocco, $61.8 \%$ of the female labour force works in the agricultural sector compared to only $43.4 \%$ of men according to the latest available statistical data from the International Labour Organization (ILO) ${ }^{6}$. While in Tunisia $70 \%$ of women are engaged in agricultural activities, when it comes to compensation their salaries are only half of what men earn. Besides inequalities in the labour market, rural women account for $65 \%$ of school dropouts and an illiteracy rate of about $30 \%$ (Bajec, 2020), which are disturbing trends considering the objectives of the International Bill of Women's Rights (CEDAW) to ameliorate the living conditions of rural women (Inter-parliamentary Union, 2003: 15, 18-19).

The most serious impact of the pandemic on women was the increase in domestic violence. The COVID-19 upheld the traditional role of men as head of the family, which resulted in increased feeling a of frustration. In Morocco, according to a study conducted between March and July, 57\% of Moroccan women experienced some forms of violence during this research period (Ennaji, 2021: 11). A significant increase in violence was also identified among Tunisian women following the outbreak of the COVID-19 pandemic. Between March and May 2020, the number of registered cases was 9 times higher than average (2,700 cases were violent out of 9,800 ) and $76 \%$ of Tunisian women experienced physical violence. Furthermore, violence also impacted the labour market in the form of deprivation of access to job opportunities as well as control of salaries. Despite the establishment of an emergency line in Tunisia for victims of violence, the restrictions caused by the pandemic resulted in a decrease of complaints registered by the Ministry of Justice (ONU Femmes, 2020: 6).

Addressing the challenges women faced required different approaches from decision-makers and NGOs, resulting in large-scale mobilization. In Tunisia, in addition to the 24/7 emergency line, a reception centre was set up by the Ministry of Women, Family, Children and Seniors to assist asylum seekers during quarantine before moving to traditional reception centres. Moreover, in collaboration with different ministries, women rights organizations launched several awareness campaigns for female victims of domestic violence (OCDE, 2020: 20-21). However, the lack of information about the real number of victims remained unknown, and except for urgent cases the activities of courts were suspended. The responses of women's rights NGOs and governments to the challenges women have faced during COVID-19 clearly demonstrate that while the current global crisis can contribute to the reconsideration of gender inequalities through the mobilization of NGOs, the lack of infrastructural facilities poses an obstacle to realizing these objectives. The following chapter will analyse the possibility of a bottom-up evolution of women's rights in light of challenges caused by the pandemic. 
A bottom-up approach to women's rights: is gender equality possible? As highlighted in the introduction, the analysis centred around the question of whether the outbreak of the pandemic triggered more intense collaboration among women's rights activists and NGOs to push decision-makers towards reevaluating problems related to gender inequality. To answer this research question, interviews were conducted with representatives and members of Moroccan and Tunisian women's rights NGOs. Four women's rights activists were selected from each country for online interviews because of the restrictions imposed by the pandemic and the limited availability of NGOs. In Morocco the four activists come from different organizations while in Tunisia two activists belong to the same organization which means that in Tunisia only three organizations were involved in the research. Founded in 2000, the Marrakesh-based High Atlas Foundation (HAF) is a Moroccan association and U.S. non-profit organization that is committed to promoting sustainable development for women and youth empowerment and education ${ }^{7}$. The other three women's rights activists came from the Rabat-based La Voix de la Femme Amazighe, ${ }^{8}$ the Without She I Would Never Be a He${ }^{9}$, and the Coalition ISRAR pour l'Empowerment et l'Égalité (ISRAR Coalition for empowerment and equality) ${ }^{10}$ organizations. The organizations involved in the empirical research demonstrate the conditions of rural women as well as the cultural and ethnical diversities of Morocco. In Tunisia questions were posed to the representative of the regional bureau of UNFT (Union Nationale de la Femme Tunisienne) in Kelibia (a city in northeastern Tunisia, belonging to Nabeul Governorate). The Tunisian UNFT is the biggest and oldest women's rights NGO established during Tunisia's independence. The organization is dedicated to working on the promotion of civil rights, participation in political life and education, and fighting against domestic violence committed against women ${ }^{11}$. The other three women's rights activists interviewed included the president of the Tunisa-based l'Association Patrimoine pour l'Economie Solidaire (APES, Heritage Association for Solidarity Economy), ${ }^{12}$ the secretary general of the Association des Femmes Tunisiennes pour la Recherche sur le Développement (AFTURD, Association of Tunisian Women for the Research on Development $),{ }^{13}$ who is also active member of the Tunisian syndicate, UGTT (Tunisian General Labour Union). ${ }^{14}$ The fourth activist interviewed is also a member of the AFTURD. The interviews took place between August and November in 2021. For the protection of personal rights, the researchers prefer to keep the interviewees' identities anonymous.

Interviews were conducted with the same list of questions, including the objectives of the associations, future challenges in light of

The most serious impact of the pandemic on women was the increase in domestic violence. The COVID-19 upheld the traditional role of men as head of the family, which resulted in increased feeling a of frustration. 
the pandemic, intra-state and regional cooperation with other NGOs, and biggest constraints for achieving gender equality. Researchers posed questions to both representatives and members of the organizations. Both the HAF and the UNFT Kelibia stated that the COVID-19 pandemic had a serious impact on public life, including the conditions of women and the previous plans and objectives of their organizations, mainly due to the cancellation of seminars and workshops. However, according to the HAF, the pandemic also urged the organization to adapt to the changing situation with a work plan and live or pre-recorded trainings involving closer cooperation with U.S. volunteers. The Tunisian AFTURD also emphasized adaptation and highlighted the advantages of teleworking. The second Moroccan NGO, La Voix de Femme Amazighe, also raised issues that reinforced the consequences of the pandemic on women the organization referred to the increase in violence committed against women). The negative impact of the pandemic on the organization resulted in the cancellation of field work, which constitutes its largest and most important objective. The decrease in the organization's financing and regional cooperation with other NGOs were also negative consequences of the pandemic. Moreover, the interviewee of La Voix de Femme Amazighe stated that "the pandemic negatively impacted the conditions of those women who work in small cooperatives and informal sectors like hammams and hairdressers, and this led to the impoverishment of women". The organization also highlighted the impoverishment of women, an opinio also shared by the Association Patrimoine pour l'Economie Solidaire. Despite admitting the negative consequences of COVID-19 on the conditions of women, Without She I Would Never Be a He emphasized that one of the positive outcomes of the pandemic was manifested in a more effective support to women. The main goal of the organization is to achieve the economic independence of women: "Of course there are negative impacts of the pandemic, like an increase in violence committed against women or impoverishment, but on the other hand we can provide more support to women. Achieving economic independence is the priority for us, it is a key to everything". Women's rights organizations in Tunisia also raised issues related to the same consequences that the Moroccan organizations discussed concerning the impact of COVID-19 on their activities. The Association Patrimoine pour l'Economie Solidaire highlighted problems related to financing the organization and the cancelling events. The member of the Moroccan Coalition ISRAR saw digitalization as a key element in the post-COVID period: "the gist of digitalization is to support illiterate women, but besides this the empowerment of women and the elimination of violence are also important". Despite the negative impacts of the pandemic on the activities of the NGOs, Coalition ISRAR believes that if an association is well organized the current crisis can contribute to the improvement of the conditions of women.

Both the HAF and the UNFT Kelibia claimed that working with other national or international NGOs with the same objectives will contribute to the creation of a comprehensive vision in terms of approaching the question of gender equality. The HAF collaborates with the Empowerment Institute in the US, and the UNFT Kelibia cooperates with the Spanish Assembly of Cooperation for Peace (ACPP).

\section{Hungarian Journal of African Studies (Afrika Tanulmányok)}


The latter observed that one advantage of the pandemic was that it brought about a bigger awareness campaign among women to ameliorate their rights. This view is also shared by the HAF referring to the need of complementary activities such as workshops to raise awareness and empower women on how to better enforce their social and economic rights. The co-founder of the Without She I Would Never Be a $\mathrm{He}$ NGO also reinforced her willingness in this matter by emphasizing the NGO's regional coordination efforts with Tunisian and Mauritanian women's rights organizations. The president of La Voix de la Femme Amazighe was the only interviewee who stated that "due to the pandemic the NGO does not continue any cooperation with other regional partners, and dialogue with Tunisian and Libyan NGOs has stopped". In the case of Tunisia the responses of NGOs were the similar to that of Morocco, with the exception of the APES, which clearly underlined that "due to problems related to the question of financing I do not believe the cooperation of women's rights organizations with the same objectives can have any positive outcome". Coalition ISRAR stated that the organization aims to create a working group that can boost the previous cooperation of the former regional initiative known as the Collectif Maghreb-Égalité 95. AFTURD evoked the advantages of intra-state and regional cooperation, stating that "only collective actions can bring about change." The initiative of the organization includes collaboration with rural associations as well as other regional or international organizations, including NGOs from Palestine, Morocco, Algeria, Egypt and Lebanon in the field of violence committed against women. Overall, the interviews proved that despite the efforts to increase regional cooperation, intra-state collaboration of NGOs remains quite strong. According to women's rights organizations, decision-makers must pay attention to such efforts to address questions and problems related to inequalities between men and women.

The most significant question was the identification of social and cultural norms that serve as constraints in realizing gender equality. There was a consensus about social, cultural and traditional norms being obstacles to equality between the sexes. The HAF identified social, cultural, and traditional norms, and the lack of access to education, the labour market, and health and legal services as the major constraints to gender equality. While the UNFT Kelibia stated that following the the Arab Spring some progress was made in the consolidation of previous achievements guaranteed by the PSC, realizing equality in job opportunities and decision-making remain two key areas where further development would be of great importance. The local NGO saw the lack of self-confidence as one of the biggest obstacles to achieving equality between men and women. In this sense, the organization played an important role in supporting several female candidates during the last municipal elections and started working on the creation of a local bureau for female entrepreneurs in Kelibia before the pandemic. The increased participation of women in decision-making was also a significant goal for the Without She I Would Never Be a He NGO in Morocco, the UNFT Kelibia, and the Association Patrimoine pour l'Economie Solidaire. Organisations in Tunisia outperformed those in Morocco in terms of women's involvement in the process of decision-making. Besides the existing traditional norms, it is also

Sipos Xénia Zsuzsanna: Evaluating the impact of COVID-19... 
of crucial importance to highlight the historical perspective and presence of maledominated norms originating from the heritage of a traditional society and the French colonial past. According to Coalition ISRAR, "there is no monitoring and no protection for women". Additionally, the availability of statistics regarding the conditions of women in Morocco and Tunisia is not sufficient, and in most cases statictics do not cover the reality. The lack of financing and a competent labour force to collaborate with local NGOs were also identified a obstacles to realizing gender equality. AFTURD highlighted the main achievements regarding the elimination of illiteracy but emphasized that the results of these measures are not apparent as inequalities are present in the labour market and in decision-making. AFTURD regarded the realization of equalit as a key to women's empowerment. According to the interviewees, the high unemployment rate of educated women who graduated from school was the most troublesome obstacle to improving the conditions of women.

When it comes to the main research question (i.e. whether women's rights organizations in Morocco and Tunisia believe in the application of a top-down approach after the Arab Spring uprising and during the COVID-19 crisis), the responses of the NGO interviewees in general were positive. HAF believes that by promoting intensive training programs and establishing local cooperatives, sub-state actors can contribute to reforming rigid social norms that clearly do not help with decreasing gender inequality. Awareness campaigns and reforms to increase the participation of women in national parliaments also play a role in women's rights NGOs, such as La Voix de la Femme Amazighe and Without She I Would Never Be a He. The latter NGO along with the Association Patrimoine pour l'Economie Solidaire also emphasized the establishment of the economic independence of women by launching different programmes as a key step towards achieving gender equality. Their emphasis on local cooperation in the bottom-up approach is vital for success. In contrast, the Association des Femmes Tunisiennes pour la Recherche sur le Développement (AFTURD) believed that the creation of an international framework for women's rights (top-down approach) could trigger collaboration on state and sub-state levels. The second interviewee from AFTURD saw the bottom-up approach as a long and careful process. According to the Coalition ISRAR, decision-makers have a limited scope to ameliorate the conditions of women. On the one hand, there needs to be a willingness to take into consideration the demands of NGOs; on the other hand, the question of gender equality is not a priority in their agenda.

However, it cannot be denied that the promotion of gender equality is often used for political purposes by decision-makers, especially in times of crisis. This transpired during the rule of President Bourguiba and Ben Ali. This fact was also reinforced by an interviewee from the Association Patrimoine pour l'Economie Solidaire, who regarded the nomination of women to political posts more like symbolic gestures than a real intention to change: "For me, the nomination of a woman as prime minister is more abou communication than a true willingness to change".

The following summary chart provides a classification of the interview questions and organizational responses,: 


\begin{tabular}{|c|c|c|c|c|c|c|c|}
\hline & \multicolumn{4}{|c|}{ Morocco } & \multicolumn{3}{|c|}{ Tunisia } \\
\hline Aspects & HAF & $\begin{array}{l}\text { La Voix de } \\
\text { la Femme } \\
\text { Amazigh }\end{array}$ & $\begin{array}{c}\text { Without } \\
\text { she I would } \\
\text { never be } \\
\text { a he }\end{array}$ & $\begin{array}{c}\text { Coalition } \\
\text { ISRAR }\end{array}$ & $\begin{array}{c}\text { UNFT } \\
\text { Kelibia }\end{array}$ & APES & $\begin{array}{c}\text { AFTURD } \\
\text { (2activists) }\end{array}$ \\
\hline $\begin{array}{c}\text { Impacts } \\
\text { of the } \\
\text { COVID-19 } \\
\text { on women's } \\
\text { rights }\end{array}$ & $\begin{array}{l}\text { serious } \\
\text { (adaption is } \\
\text { possible) }\end{array}$ & $\begin{array}{l}\text { serious } \\
\text { (impover- } \\
\text { ishment of } \\
\text { women) }\end{array}$ & $\begin{array}{l}\text { serious } \\
\text { (increase } \\
\text { of domestic } \\
\text { violence) }\end{array}$ & $\begin{array}{l}\text { highlighting } \\
\text { the vulner- } \\
\text { ability of } \\
\text { women, } \\
\text { digitaliza- } \\
\text { tion as a key }\end{array}$ & serious & \begin{tabular}{|l} 
serious \\
(reinforce- \\
ment of \\
inequalities, \\
increased \\
domestic \\
violence)
\end{tabular} & $\begin{array}{l}\text { serious (impov- } \\
\text { erishment of } \\
\text { women) }\end{array}$ \\
\hline $\begin{array}{l}\text { Intra-state } \\
\text { and regional } \\
\text { cooperation }\end{array}$ & $\begin{array}{l}\text { will of } \\
\text { cooperation } \\
\text { international } \\
\text { cooperation } \\
\text { with the US } \\
\rightarrow \text { positive } \\
\text { experiences }\end{array}$ & $\begin{array}{l}\text { will of } \\
\text { cooperation, } \\
\text { but outbreak } \\
\text { of the } \\
\text { pandemic } \\
\text { (belief in } \\
\text { domestic } \\
\text { coopera- } \\
\text { tion ) }\end{array}$ & $\begin{array}{l}\text { will of } \\
\text { cooperation } \\
\text { (e.g. Tuni- } \\
\text { sian and } \\
\text { Mauritanian } \\
\text { partners) }\end{array}$ & \begin{tabular}{|l} 
will of \\
coopera- \\
tion (e.g. \\
Algerian, \\
Maurita- \\
nian, Libyan \\
and Tuni- \\
sian NGOs \\
+ rural asso- \\
ciations) \\
$\rightarrow$ creation \\
of working \\
groups+ \\
forums \\
\end{tabular} & $\begin{array}{l}\text { will of } \\
\text { cooperation } \\
\text { Spanish } \\
\text { support } \rightarrow \\
\text { positiveexpe- } \\
\text { riences }\end{array}$ & $\begin{array}{l}\text { pessimistic } \\
\text { scenario } \rightarrow \\
\text { problems of } \\
\text { financing, } \\
\text { more con- } \\
\text { fidence in a } \\
\text { Northern- } \\
\text { Southern } \\
\text { cooperation }\end{array}$ & $\begin{array}{l}\text { wider regional } \\
\text { and interna- } \\
\text { tional (French } \\
\text { and Spanish } \\
\text { NGOs) cooper- } \\
\text { ation before the } \\
\text { Arab Spring } \\
\text { reinforcement } \\
\text { of intra-state } \\
\text { cooperation } \\
\text { after } 2011\end{array}$ \\
\hline $\begin{array}{l}\text { Outcome of } \\
\text { the pandemic }\end{array}$ & $\begin{array}{l}\text { positive } \\
\text { impact } \rightarrow \\
\text { need for } \\
\text { comple- } \\
\text { mentary } \\
\text { activities } \\
\text { (workshops) } \\
\rightarrow \text { empow- } \\
\text { erment of } \\
\text { women }\end{array}$ & $\begin{array}{l}\text { negative } \\
\text { impact } \rightarrow \\
\text { financial } \\
\text { cut, termi- } \\
\text { nation of } \\
\text { field work } \\
\text { and regional } \\
\text { cooperation }\end{array}$ & $\begin{array}{l}\text { negative } \\
\text { impact } \rightarrow \\
\text { possibility } \\
\text { to support } \\
\text { women's } \\
\text { economic } \\
\text { independ- } \\
\text { ence as a } \\
\text { key area }\end{array}$ & $\begin{array}{l}\text { question of } \\
\text { adaptation }+ \\
\text { financing }= \\
\text { ameliora- } \\
\text { tion of the } \\
\text { conditions } \\
\text { of women }\end{array}$ & $\begin{array}{l}\text { positive } \\
\text { impact } \rightarrow \\
\text { intensive } \\
\text { awareness } \\
\text { campaign }\end{array}$ & $\begin{array}{l}\text { negative } \\
\text { impact } \rightarrow \\
\text { termination } \\
\text { of seminars, } \\
\text { cut in the } \\
\text { financing }\end{array}$ & \begin{tabular}{|l} 
negative \\
impact, but \\
positive con- \\
sequences for \\
rural women $\rightarrow$ \\
lower impact of \\
the pandemic \\
$2^{\text {nd }}$ activist: \\
teleworking \\
as a positive \\
impact \\
\end{tabular} \\
\hline $\begin{array}{c}\text { Barriers } \\
\text { to gender } \\
\text { equality }\end{array}$ & $\begin{array}{l}\text { social, } \\
\text { cultural and } \\
\text { traditional } \\
\text { norms; lack } \\
\text { of access to } \\
\text { education, } \\
\text { labour mar- } \\
\text { ket, health } \\
\text { services; } \\
\text { lack of legal } \\
\text { awareness }\end{array}$ & $\begin{array}{l}\text { presence } \\
\text { of laws } \\
\text { in favour } \\
\text { of men, } \\
\text { regional } \\
\text { and cultural } \\
\text { inequalities, } \\
\text { patriarchal } \\
\text { society }\end{array}$ & $\begin{array}{l}\text { cultural, } \\
\text { political, } \\
\text { glass-ceil- } \\
\text { ing effect in } \\
\text { the labour } \\
\text { market }\end{array}$ & $\begin{array}{l}\text { lack of } \\
\text { monitoring, } \\
\text { reliability } \\
\text { of statistical } \\
\text { data, lack of } \\
\text { competence }\end{array}$ & $\begin{array}{l}\text { lack of job } \\
\text { opportuni- } \\
\text { ties, limited } \\
\text { access to } \\
\text { decision- } \\
\text { making, } \\
\text { lack of self- } \\
\text { confidence }\end{array}$ & $\begin{array}{l}\text { social, } \\
\text { economic, } \\
\text { juridic, } \\
\text { educational, } \\
\text { political }\end{array}$ & $\begin{array}{l}\text { need for change } \\
\text { in mentality } \rightarrow \\
\text { heritage of the } \\
\text { historical past } \\
\text { unemploy- } \\
\text { ment of female } \\
\text { graduates }\end{array}$ \\
\hline $\begin{array}{l}\text { Bottom-up } \\
\text { approach }\end{array}$ & $\begin{array}{l}\text { yes, estab- } \\
\text { lishment of } \\
\text { local coop- } \\
\text { eratives, } \\
\text { intensive } \\
\text { training } \\
\text { programs }\end{array}$ & $\begin{array}{l}\text { yes, the key } \\
\text { is political } \\
\text { participation } \\
\text { of women } \\
+ \text { local } \\
\text { coopera- } \\
\text { tion, local } \\
\text { projects }\end{array}$ & $\begin{array}{l}\text { depends on } \\
\text { the current } \\
\text { political } \\
\text { context }+ \\
\text { economic } \\
\text { indepen- } \\
\text { dence+ }+ \\
\text { political will }\end{array}$ & $\begin{array}{l}\text { willing- } \\
\text { ness does } \\
\text { exist with } \\
\text { decision- } \\
\text { makers, but } \\
\text { difficult }\end{array}$ & - & $\begin{array}{l}\text { rather pessi- } \\
\text { mistic view } \\
\text { depends on } \\
\text { the political } \\
\text { context }\end{array}$ & $\begin{array}{l}\text { partly }+ \text { impor- } \\
\text { tance of the } \\
\text { international } \\
\text { framework of } \\
\text { women's rights } \\
\text { (CEDAW)after } \\
\text { 2011 bottom-up } \\
\text { approach) }\end{array}$ \\
\hline
\end{tabular}

$\bigwedge$ Table 2. Summary chart based on interviews ${ }^{15}$ with representatives of the Moroccan and Tunisian NGOs 


\section{Conclusion}

The article analysed the question of gender equality from a new perspective that included the feminist approach to IR, positioning the study in the framework of complex interdependence theory that emerged at the end of the 1970s and had a significant impact on decision-makers. While the absence of women in the main decision-making and economic processes clearly demonstrates that international relations are strongly gendered, the study dealt with the question of to what extent sub-state actors can influence the behaviour of states. In this regard, the article elaborated a model that showcases the relationship between the various NGOs and the states, finding that the evolution of women's rights is strongly dependent on the historical, political, economic, cultural, and social processes in Morocco and Tunisia. In Morocco, the lack of the centralization of power and the presence of a tribal system brought about the consolidation of a patriarchal society, which was reinforced following the adoption of a conservative family law in 1957. Concerning the political characteristics of a certain state, it must be highlighted that states' support for gender equality also serves as a tool to show off to the international community, with leaders often utilizing women's rights as a political card to play against their opponents. In Tunisia this scenario took place after 1956 (state feminism), and in contrast to Morocco resulted in a higher HDI index, a lower GII, and more developed educational and healthcare systems. In Morocco, women's rights NGOs needed to fight for an extended period of time to bring about significant development.

The outbreak of the COVID-19 pandemic has already had a grave effect on global economic development. According to official statistical data, both Morocco and Tunisia faced serious economic and social crises before COVID-19. In Tunisia, the GDP growth was $2.7 \%$ and the unemployment rate for women reached $16.7 \%$ (PNUD-MDICI, 2020: 10-11, 40). In Morocco, one million people lost their jobs in the first four months following the outbreak of the pandemic and the unemployment rate reached $33.4 \%$ for $15-24$ year-olds, $18.2 \%$ for graduates, and $15.6 \%$ for women (Ennaji, 2021:8-9). The article began by discussing the feminist approach, which refers to the inferior position of women in all fields of society. Following the overview of qualitative data from interviews, the study found that despite the presence of anarchy on the level of sub-state actors and states (micro and mezzo levels), this anarchy can be modulated through the interaction of sub-state actors and states. The Arab Spring uprising beginning in December 2010 demonstrated that crises can pave the way for different NGOs to mobilize for the benefit of the vulnerable groups, which can contribute to bringing about significant positive social development. In this regard, the question of gender equality can be understood as a bidirectional process in which the presence of some traditional, culturally established norms means an obstacle for women's rights NGOs and states alike. However, both sub-state actors and the international community can exercise pressure on states to act. The study proved that the pandemic could bring about the amelioration of women's rights as states were pushed to rethink how social peace could be preserved.. However, in the long run this conclusion must be considered with caution. The empirical findings 
also reinforced the fact that achieving progress is a long process that must include sustained support from sub-state actors and decision-makers, with a clear strategy for equal treatment of women in regards to their social, economic, and political rights.

\section{Notes}

1 The full text of the Personal Status Code or Code du Statut Personnel (PSC) adopted in 1956 by the first president of Tunisia, Habib Bourguiba, can be accessed via the link mentioned in the bibliography.

2 Created by the United Nations Development Programme (UNDP), the Gender Inequality Index (GII) measures inequalities on three main dimensions: reproductive health, empowerment, and the labour market with different indicators in each dimension. Access to the UNDP indicators can be found in the bibliography.

${ }^{3,4,5,6}$ The official data of UNESCO, the Moroccan High Commission of Planing (HCP), IPU, ILO can be accessed via the links mentioned in the bibliography.

$7,8,9,10,11,12,13,14,15$ The official websites of the for Moroccan HAF, La Voix de la Femme Amazighe, Coalition ISRAR, Tunisian UNFT Kelibia and APES can be found in the bibliography. Information on the activities of the women's rights the Moroccan and Tunisian organizations Without She I Would Never Be a He and AFTURD was only available on their official Facebook pages. ${ }^{15}$ The questions asked during the interviews can be found in the Appendix.

\section{Appendix}

Questions asked from the representatives of HAF and UNFT Kelibia

1. To what extent did the pandemic situation effect the main objective(s) of your organisation? What are/were the main challenges to cope with for the future?

2. Besides the negative impacts of the pandemic on women's empowerment, how can the post-COVID period lead to the amelioration of certain conditions of young women and women in general? Or, do you believe that the pandemic will further reinforce the already existing inequalities?

3. How do you see the cooperation with other NGOs in the field of education? In this regard, how do you see the prospects of collaboration among other associations that represent the same objectives? Do you believe a certain kind of top-down approach can have a great impact on decision-makers?

4. How can regional cooperation among associations with the same objectives be feasible for achieving gender equality?

5. How do you see the process of shaping feminine norms before and after the Arab Spring events of 2011? How has COVID-19 impacted -the question of gender equality?

6. What do you see as the biggest barrier to realizing gender equality?

7. How do you cope with the presence of traditional practices and norms when working on realizing the main objectives of your organisation?

8. How and to what extent can your organisation contribute to ameliorating women's empowerment in your country?

9. Please name some success stories among those women you support or supported. Who achieved high positions in political or economic fields (e.g., politicians, entrepreneurs)? 
10. To what extent did your organisation succeeded in eliminating illiteracy during its operation?

11. How could schools and professors provide continuous education during the pandemic (e.g., access to internet, etc.)?

12. Do you believe that by realizing your main objectives you can overwrite the existing traditional norms and practices that create a burden in front of achieving gender equality? Why/why not?

13. What impact can your organisation have on decision-makers? How can it influence decision-makers and the field of policy-making in a world traditionally dominated by men?

14. How can your organisation succeed in rewriting socially and culturally constructed barriers that hinder achieving gender equality?

15. How can women contribute to the process of democratization?

16. How can the gender gap between men and women be reduced?

17. How can society have an impact on decision-makers and NGOs?

\section{References}

- Association Patrimoine pour l'Économie Solidaire (APES), http://www.apes.tn/fr (Retrieved on 15 November)

- Bajec, Alessandra (2020): “Tunisia: COVID-19 Increases Vulnerability of Rural Women". Arab ReforM Initiative. https://www.arab-reform.net/publication/tunisia-covid-19-increasesvulnerability-of-rural-women/ (Retrieved on 13 August, 2021)

- Chabchoub, Ahmed (2014): Bourguiba et Moi. Dubai: Al Manhal Coalition Israr, https://www. democracyendowment.eu/en/our-work/initiatives/4404-coalition-israr.html (Retrieved on 15 November, 2021)

- Code du Statut Personnel. (Issued on 28 December 1956, with the latest modifications taking place on 26 July, 2010). Imprimerie Officielle de la République Tunisienne Publications de l'Imprimerie Officielle de la République Tunisienne 2012. https://www.ilo.org/dyn/natlex/ natlex4.detail?p_lang $=$ fr\&p_isn $=73374 \&$ p_count $=96182 \& p$ classification $=01.03 \& p$ _classcount=1024 (Retrieved on 1 August, 2021)

- Convention on the Elimination of All Forms of Discrimination Against Women [1979]. New York, 18 December 1979.United Nations Treaty Collection.https://treaties.un.org/pages/ViewDetails.aspx?src $=I N D \& m t d s g \_n o=I V-8 \&$ chapter $=4 \&$ clang $=$ en\#EndDec (Retrieved on 9 December, 2021)

- Darhour, Hanane - Dahlerup, Drude (2020): Double-Edged Politics on Women's Rights in the MENA Region. London: Palgrave Macmillan.

- Ennaji, Moha (2021): "Women and Gender Relations during the Pandemic in Morocco". Gender and Women Studies. Vol. 4., No. 3., 1-25 pp.

- Haut Comissariat au Plan, HCP (High Commission of Planning), www.hcp.ma (Retrieved on 16 August, 2021)

- High Atlas Foundation (official website), https://highatlasfoundation.org/ (Retrieved on 23 August, 2021)

- ILOSTAT explorer. https://www.ilo.org/shinyapps/bulkexplorer2/ (Retrieved on 10 August, 2021)

- Inter-Parliamentary Union(IPU) Parline. Global data on national parliaments. Monthly ranking of women in national parliaments. https://data.ipu.org/women-ranking?month=1\&year=2021 (Retrieved on 10 August, 2021) 
- Inter-Parliamentary Union (2003): “The Convention on the Elimination of All Forms of Discrimination against Women (CEDAW) and its Optional Protocol. Handbook for Parliamentarians". https://www.ipu.org/resources/publications/handbooks/2016-07/ handbook-parliamentarians-convention-elimination-all-forms-discrimination-againstwomen-and-its-optional (Retrieved on 7 August, 2021)

- Jewkes, Rachel et al. (2015): "Hegemonic masculinity: combining theory and practice in gender interventions". Culture, Health\&Sexuality. An International Journal for Research, Intervention and Care. Vol. 17., No. 2., 112-127 pp.

- Jomier, Augustin (2011): "Secularism and State Feminism: Tunisia's Smoke and Mirrors". Books and Ideas. https://booksandideas.net/Secularism-and-State-Feminism.html (Retrieved on 10 August, 2021)

- Keohane, Robert O. (1998): "Beyond Dichotomy: Conversations Between International Relations and Feminist Theory". International Studies Quarterly. Vol. 42., 193-198 pp.

- Kimani, Mary. 2008: "Women in North Africa secure more rights". Africa Renewal. https:// www.un.org/africarenewal/magazine/july-2008/women-north-africa-secure-more-rights (Retrieved on 5 August, 2021)

- La Voix de la Femme Amazighe. Euro-Mediterranean Women's Foundation. https://www. euromedwomen.foundation/pg/fr/profile/ermwf.lvfa (Retrieved on 15 November, 2021)

- Mail, Erica (2019): "Women's Rights in Tunisia Before and After the 2011 Revolution: Progress When It Helps the People in Power". International Immersion Program Papers. University of Chicago Law School. htts://chicagounbound.uchicago.edu/cgi/viewcontent.cgi?article=1113\& context=international_immersion_program_papers (Retrieved on 19 August, 2021)

- Mazou, Aude (2021): “ Le drôle de nomination de Najla Bouden à la tête du gouvernement tunisien”. France 24., https://www.france24.com/fr/afrique/20211001-la-dr\%C3\%B4le-de-nomination-de-najla-bouden- $\% \mathrm{C} 3 \% \mathrm{~A} 0-\mathrm{la}-\mathrm{t} \% \mathrm{C} 3 \% \mathrm{AAte}$-du-gouvernement-tunisien (Retrieved on 28 October, 2021)Ministère de la Femme, de la Fertilité et de l'Enfance. "Stratégie nationale pour l'autonomisation économique et sociale des femmes et des filles rural, 2017-2020". http://www.femmes.gov.tn/wpcontent/uploads/2017/07/Presentation_Strategie__FR_20 17-2020.pdf (Retrieved on 15 August, 2021)

- Moghadam, Valentine M. (2014): "Modernising women and democratisation after the Arab Spring”. The Journal of North African Studies. Vol. 19., No. 2., 137-142 pp.

- Nye, Joseph S. - Keohane, Robert O. (1971): “Transnational Relations and World Politics: An Introduction". International Organization. Vol. 25., No. 3., 329-349 pp.

- OCDE (2020): "COVID-19 dans la région MENA: impact sur les inégalités de genre et réponses apportées en soutien aux femmes. Lutte contre le coronavirus (COVID19). Pour un effort mondial“. https://www.oecd.org/coronavirus/policy-responses/ covid-19-dans-la-region-mena-impact-sur-les-inegalites-de-genre-et-reponses-apportees-ensoutien-aux-femmes-f7da7585/ (Retrieved on 5 August, 2021)

- OECD-ILO-CAWTAR (2020): "Changing Laws and Breaking Barriers for Women's Economic Empowerment in Egypt, Jordan, Morocco and Tunisia”. Competitiveness and Private Sector Development. https://www.ilo.org/wcmsp5/groups/public/---africa/---ro-abidjan/--sro-cairo/documents/publication/wcms_760505.pdf(Retrieved on 2 August, 2021)

- ONU Femmes (2020): "Tunisian women in the face of COVID-19: during and after confinement". https://arabstates.unwomen.org/en/digital-library/publications/2020/07/policybrief-tunisian-women-in-the-face-of-covid19 (Retrieved on 18 August, 2021)

- Organisation des Nations Unies pour l'Éducation, la Science et la Culture. Institut de Statistique de l'UNESCO. http://uis.unesco.org/fr/home (Retrieved on 10 August, 2021)

- PNUD-Ministère du Développement, de l'Investissement et de la Coopération Internationale (2020): "Impact économique du COVID-19 en Tunisie. Analyse en termes de vulnérabilité des ménages et des micro et très petites entreprises“. https://www.tn.undp.org/ 
content/tunisia/fr/home/library/environment_energy/etude-sur-l-impact-economique-ducovid-19-en-tunisie-.html (Retrieved on 25 August, 2021)

- Ruiz, Tricia (2005): "Feminist Theory and International Relations: The Feminist Challenge to Realism and Liberalism". Soundings Journal., 1-7 pp.

- Sadiqi, Fatima (2008): "Facing Challenges and Pioneering Feminist and Gender Studies: Women in Post-colonial and Today's Maghrib". African and Asian Studies. Vol. 7., 447-470. pp.

- Scott, Joan W. (1986): “Gender: A Useful Category of Historical Analysis". The American Historical Review. Vol. 91., No. 5., 1053-1075 pp.

- Tickner, J. Ann (1992): Gender in International Relations. Feminist Perspectives on Achieving Global Security. New York: Columbia University Press

- Union Nationale de la Femme Tunisienne (official website), https://www.unft.org.tn/fr/pagedaccueil (Retrieved on 25 August, 2021)

- Union Générale Tunisienne du Travail, http://www.ugtt.org.tn/ (Retrieved on 15 November, 2021)

- United Nations Development Programme. Human Development Reports, http://hdr.undp.org/ en/home (Retrieved on 26 August, 2021)

- UN WOMEN (2015): „Summary Report: The Beijing Declaration and Platform for Action turns 20". https://www.unwomen.org/en/digital-library/publications/2015/02/beijing-synthesis-report (Retrieved on 15 August, 2021) 